\title{
Research on the Maturating of Technological Achievements to Improve the Level of Patent Management in Ningbo
}

\author{
Lili Ma $^{1, a}$, Yujun Duan ${ }^{2, b}$ \\ (Ningbo Dahongying University,Ningbo 315175) \\ ${ }^{1-2}$ No.899. Xueyuan Road, Yinzhou District, Ningbo City,Zhejiang Prov, China \\ a 78858361@qq.com, ${ }^{b}$ 38213912@qq.com
}

Key words: patent management; the maturating of technological achievements; Ningbo ;

Abstract. With the improvement of the national IP strategy and system, the number of IP applications and grants is increasing between high-tech enterprises. It is an important issue to business managers of high-tech companies that how to use the intellectual property effectively. This paper summed up the important roles of patent management in Ningbo, analyzes the maturating conditions, mechanism and models of technological achievements, it provides the corresponding countermeasures of patent management.

\section{Introduction}

The study of the phenomenon and the rule of regional innovation system is the important component of promoting regional innovation and is the important measures for realizing the regional sustainable development and is also the immportant steps s to realize national regional development strategy. It is necessary to establish regional innovation system that can not leave the regional innovation investment. Now, each region in China with $R \& D$ investment as the main sign of regional innovative investment has a improved greatly. Regional innovation direct performance, namely the regional innovation input and output relationship, has been studied deeply for the politics, the industry and the academic circle. There appear a large number of research results, and some useful conclusions are obtained. But, some questions, for examlpe which kinds of influence will be produce for regional innovation investment to Chinese macroeconomic and regional innovation investment indirect performance and its evaluation, have yet to introduce paid enough attention.

\section{The important roles of Patent Management in Ningbo}

2.1 National level: Promoting patent operating has an important practical significance in accelerating independent innovation capability and economic innovation and development.The 13th Five-Year Guideline has made it clear to the "implement intellectual property strategy, improve intellectual property legal system, strengthen the creation, utilization, protection and management of IPR" elevate these to national development strategic plan, All these fully shows that intellectual property have become national strategy. It has reported that "focusing on guiding and supporting innovative elements into enterprises, accelerating the establishment of enterprises as the mainstay, market-oriented, a combination of technological innovation system, promote the establishment of strategic innovation alliances incltiding enterprises, research institutes and universities, make entrepreneurs and leading scientists playing an important role in science and technology innovation.” stressed the importance of the establishment of technology innovation system. Innovation and technological achievements have become an assessment factor which measure an innovative country. Innovation and technological achievements under market economy conditions, these are more pronimnent performing on implementation and transformation. Patent is the most central part in innovation and technological achievements. So the level of conversion rate of scientific and technological achievements closely related to the level patent conversion rate. For the reason that, promoting patent operating has an important practical significance in accelerating independent innovation capability and economic innovation and development. 
2.2 Government level: Construction of a complete and effective intellectual property management system is an important relying on science and technology and rejuvenating the country.Under the background of the era of knowledge economy, the international competition has from resources and capital competition into a high cutting-edge technology competition up, countries in battle has gradually focused on new technology in production and new equipment of wars, master frontier science and technology technologies and have high-end technology has become the common goal, and is thus China's high technology enterprise present and future developments in relation to the China can in the fierce international competition get ahead and to realize national core competitiveness and the strengthening of comprehensive national strength.

High technology enterprise in the forefront of cutting-edge technologies, in constant innovation to create the new technology at the same time is more important to the effective management of intellectual property, using existing patent and other intellectual property system features and functions of intellectual property of exploitation, protection and operation in overall arrangement and unified planning.

Therefore, from high technology enterprises and their own conditions, technical environment and competitive situation based on the implementation of intellectual property strategy, build a comprehensive effective intellectual property strategy management system is a national science and technology and rejuvenating the country important rely on, is to safeguard national first strategic reserves, is an important guarantee of high technology enterprises to actively urge innovation motivation, bearing maintain and develop the ability of independent innovation and independent intellectual property rights of the important mission, to safeguard the interests of the state and economic security to have the important meaning.

2.3 Enterprise level: Technological innovation is an important source of maintenance and development of the core competitiveness of enterprises. Technological innovation is the key factors of a country gaining a competitive advantage and achieving sustainable development, especially for the main body of market competition, enterprises. Enterprise scan through the development of new technology to reduce the product cost, by introducing a new product to create more customers demand, so as to improve the competitiveness of the enterprises in the market, to obtain a higher operating pro fit. R\&D input and patent output are the key link in the process of innovation chain, they focus on the different nature and different stages in the process of innovation activities respectively. More and more enterprises have realized the technology innovation is the important source of keeping and developing the core competitiveness. In such a case that small and medium enterprises is not the dominant situation in capital scale, how to use technology innovation to enhance their core competitiveness is an important strategy in their survival and development.

The independent innovation involves original innovation and integration innovation and imitation innovation. For most enterprises in China, integration innovation that bases on technology, market, strategy and organization is more practical than the other two. Technology-integrated innovation is the main form of the integration innovation, which is quite different from original innovation and imitation innovation. The administration of the integration technology patent is also differing from the traditional mode. So, this thesis focuses on the special patent problems during the enterprises' technology-integrated innovation, and brings forward the strategies of the patent administration, that's quite important for the enterprises carrying out the technology-integrated innovation. The objective of this study is to search for the patent administration mode and strategies that fit for the enterprises' technology-integrated innovation, to advance the exploitation and production of the valuable integration technology and then to protect and exert the patent. Then the cluster of integration technology will grow into a commercial tool for the enterprises in the international market, and bring more profits to the technology-integrated innovation. 


\section{An important part of patent management: The Maturating of Technological Achievements}

Comparative Analysis of Ningbo City and the 15 sub-provincial cities patent applications and authorization status display, In recent years, Ningbo patent development with remarkable results, But there are still some problems to be solved patent quality, level and structure . Mainly due to the impact of patent development has $R \& D$ investment intensity is low, industrial structure needs to be further optimized, shortage of high-level innovative talents, patent enterprise management needs to be improved, patent subsidy policy to be further improved. This needs to take appropriate measures to promote innovation and development in Ningbo.

3.1 The Maturating of Technological Achievements. As a term in Technological Innovation Studies, the maturation of technological achievements refers to the process which starting from the $R \& D$, and ends with the emerging of new industries in markets after repetitive tests within. A general maturating process consists of four stages: basing products or services on technology, market-orienting of products and services, fixing patterns of management and souring finance from multiple origins, all of which forms the necessary procedures in industrialization.

3.2 The maturating conditions of technological achievements. The maturating needs for technical achievements are due to the serious "divorce" and imbalance between the abundant supplies of technical achievements and the pressing demands from the industries. In other words, the industries find these technical achievements are immature and impractical, and the technology inventions derived from them cannot be industrialized, which leads to their failure in technological innovation. Thus, the critical crux of technical achievement translating into practical productive forces lies in the maturation of technical achievements. The consequences of neglecting their maturation will cause the following problems, that is, the Research and Development (R\&D) achievements cannot be transformed into products, products are not market-oriented, the supporting management and business modes of such products will be unsystematic and ineffective, and the investment will be inadequate. Moreover, the neglect will in turn sever the link between R\&D and innovation, affect the quantity and quality of the transformation of technical achievements, and largely weaken the role of technological innovation in promoting economic growth.

3.3 The mechanism and models of technological achievements. Technical support is starting point of the maturating of technological achievements and the growth of new enterprises. The inherent reason of the maturating is the creativity and novelty of these achievements. The sub-process of basing products or services on technology includes the development of product or service prototype on the basis of knowledge, and the iterative improvement from the product or service prototypes to the quasi-commodities/services. Technical elements in technology ecosystem are mutually related, cross-fertilized, coordinated and co-existent and they also compete with or even replace each other. Moreover, there exist a number of subjective and objective restrictive factors in title sub-process of basing products or services on technology.

In the market supporting conditions, market share is one of the important criteria for the maturation of technical achievements. Products continue developing and maturating in their market-orienting process, and the development and maturation of products result from the joint effects of technology and marketing. The process needs to go through the stages of market cultivation, market division, target market selection and realization of product-marketing.

In the maturation of technical achievements,external "financial gap" have always been found in technological startups. Theoretical explanation about the financing difficulties in technological startups is information asymmetry, no difference in interest rates, high financing costs, low reputation and legitimacy of these new ventures. These startups need financial support in various development stages. During the early stage of their development, these startups face the tighter external financing constraints and narrower financing channels, and the capital has more restriction on the development of these enterprises. With the growing and maturating of technological startups, their demand for funds is also increasing, the level of their financing socialization continues to increase, and their financing structures and channels become more and more complex and diverse. The main arrangements of financing socialization for the growth and maturation of technological startups 
consist of three methods: government-guided fund, entrepreneurial finance, and the combination of technology with finance.

\section{Conclusion}

The independent innovation involves original innovation and integration innovation and imitation innovation. For most enterprises in China, integration innovation that bases on technology, market, strategy and organization is more practical than the other two. Technology-integrated innovation is the main form of the integration innovation, which is quite different from original innovation and imitation innovation. The administration of the integration technology patent is also differing from the traditional mode. So, this thesis focuses on the special patent problems during the enterprises' technology-integrated innovation, and brings forward the strategies of the patent administration, that's quite important for the enterprises carrying out the technology-integrated innovation. The objective of this study is to search for the patent administration mode and strategies that fit for the enterprises' technology-integrated innovation, to advance the exploitation and production of the valuable integration technology and then to protect and exert the patent. Then the cluster of integration technology will grow into a commercial tool for the enterprises in the international market, and bring more profits to the technology-integrated innovation.

\section{Acknowledgements}

This work was financially supported by the Ningbo Science and Technology Bureau (2014A10077,2015A10075), Zhejiang Association of Social Sciences (2015N037).

\section{References}

[1] SJ Haakonsson, JK Kirkegaard.Configuration of technology networks in the wind turbine industry. A comparative study of technology management models in European and Chinese lead firms[J]. International Journal of Technology Management, 2016,70(4):821-848.

[2] Audretsch D B, Feldman M. Knowledge spillovers and the geography of innovation[J]. Handbook of Urban and Regional Economics, 2014, 4: 2713-2739.

[3] Capello R, Varga A. Knowledge creation and knowledge diffusion in space and regional innovation performance: Introductory remarks[J]. The Annals of Regional Science, 2013, 51(1): 113-118.

[4] Chiou T Y, Chan H K, Lettice F, Chung S H. The Influence of Greening the Suppilers and Green Innovation on Environmental Performance and Competitive Advantage in Taiwan[J]. Transportantion Research Part E: Logistics and Transportantion Review, 2013, 47(6): 822-836.

[5] Doloreux D, Parto S. Regional innovation systems: Current discourse and unresolved issues[J]. Technology in Society, 2015, 27(2): 133-153.

[6] Getis A, Ord J K. The analysis of spatial association by use of distance statistics [J]. Geographical Analysis, 2012, 4(3): 189-206.

[7] Jeremy H. Innovation and regional development: A matter of perpective[J].Research Policy, 2015, 34(8): 1220-1234.

[8] Romer P M. Endogenous technological change[J]. The Journal of Political Economy, 2014, 98(5): 71-102. 